\title{
Furniture dimensions and postural overload for schoolchildren's head, upper back and upper limbs
}

\author{
Mariana Vieira Batistão ${ }^{a}$, Anna Cláudia Sentanin ${ }^{a}$, Cristiane ShinoharaMoriguchi $^{a}$, Gert-ÅkeHansson ${ }^{b}$, \\ Helenice Jane Cote Gil Coury ${ }^{a}$, Tatiana de Oliveira Sato ${ }^{a^{*}}$ \\ ${ }^{a}$ Deparment of Physiotherapy, Federal University of São Carlos, Rodovia Washington Luís, km 235 - SP-310 \\ CEP: 13565-905, São Carlos - SP-Brazil \\ ${ }^{b}$ Department of Occupational and Environmental Medicine, University Hospital, SE-221 85 Lund, Sweden
}

\begin{abstract}
The aim of this study was to evaluate how the fixed furniture dimensions match with students' anthropometry and to describe head, upper back and upper limbs postures and movements. Evaluation was performed in 48 students from a Brazilian state school. Furniture dimensions were measured with metric tape, movements and postures by inclinometers (Logger Tecknologi, Åkarp, Sweden). Seat height was high for $21 \%$ and low for $36 \%$ of the students; seat length was short for $45 \%$ and long for $9 \%$ and table height was high for $53 \%$ and low for $28 \%$. Regression analysis showed that seat/popliteal height quotient is explained by $90^{\text {th }}$ percentile of upper back inclination $(\beta=0.410)$ and $90^{\text {th }}$ percentile of right upper arm elevation $(\beta=-0.293)$. For seat/thigh length quotient the significant variables were $90^{\text {th }}$ percentile of upper back velocity $(\beta=-0.282)$ and $90^{\text {th }}$ percentile of right upper arm elevation $(\beta=0.410)$. This study showed a relationship between furniture mismatch and postural overload. When the seat height is low students increase upper back left inclination and right upper arm elevation; when the seat is short students decrease the upper back flexion velocity and increase right upper arm elevation.
\end{abstract}

Keywords: classroom, anthropometry, children, direct measurement techniques, inclinometer

\section{Introduction}

Schoolchildren spend as much as $30 \%$ of their waking hours at school, adopting sitting posture during considerable amount of time[20,21,28]. Frequently the furniture has dimensions not compatible with their anthropometric measures, which can lead tomusculoskeletal disorders, such as pain, discomfort and postural deviations [28]. Pain in this age group is well described in the specialized literature, and could be related to ergonomic risk factors [23]. One of them is the mismatch between furniture and anthropometric measures [27]. This mismatch also can lead to lack of attention during classes, as children and adolescents seek more comfortable positions, compromising learning and school performance [28].

Back pain complaints in childhood and adolescence are important risk factor for back pain in adulthood [19]. In this sense, studies strongly suggest the need for early initiatives in order to prevent the occurrence of chronic pain in schoolchildren [20].

The school furniture has an important role in maintaining the correct posture [21,17,22], facilitate learning through providing a comfortable and stressfree workstation [17] and preventing symptoms [10]. The use of adjustable furniture is essential for the healthy development of children [8] and for good postural habits in childhood [21].

\footnotetext{
*Corresponding author e-mail: tatisato@ufscar.br
} 
The adequacy of school furniture depends on the anthropometric measurements of its users. Specific measures are needed to determine the dimensions of furniture in order to allow a correct sitting posture $[17,22]$. According to Panagiotopoulos et al. [21] most children use chairs with height and length greater than recommended, generating an inappropriate adjustment to their anthropometric characteristics.

Although several studies have showninadequacy of furniture for students, few of them evaluated the response of the individual, in terms of postural risk, during the use of furniture in a real situation, as Gil and Tunes [12] performed. Then, the aim of this study was to evaluate the suitability of school furniture and its relationship with head, upper back and upper limbs postures and movements of students from fifth and eighth grade of elementary education at a Brazilian state school.

\section{Methods}

\subsection{Study settings and sample}

The study was conducted in a state school in São Carlos, São Paulo, Brazil. The study sample was selected from the population of students from two classes, $5^{\text {th }}$ and $8^{\text {th }}$ grade of elementary school, enrolled in afternoon classes. These grades were chosen to represent the most extremes students, i.e., the lowest and highest ones. Twenty four studentsfrom each grade, being 12 female and 12 male,were randomly selected to participate, which represents $75 \%$ of two classes from the $5^{\text {th }}$ and $8^{\text {th }}$ grades. The parents or guardians signed an informed consent, following the recommendations of 196/96 Brazilian Ethics Resolution. This study was approved by the Ethics Committee of the Federal University of São Carlos (CAAE 0124.0.135.000-08, Opinion N. 039/2009).

The criteria for inclusion in the sample were attending the $5^{\text {th }}$ or $8^{\text {th }}$ grade of elementary school and to be right-handed. The exclusion criteria were not complete all the evaluation procedures and the occurrence of technical problems during the movement analysis.

\subsection{Equipments and instruments}

Anthropometric and furniture measurements were obtained from a metric tape and recorded in a standardized form. Inclinometers were used for recording postures and movements for the head, upper back and upper arms(Logger Tecknologi, Åkarp, Sweden).We also used a digital camcorder (Sony DCR-SR85), tripod or other support materials.

\subsection{Furniture evaluation}

Only one kind of furniture with fixed dimensions was available in the classroom. The seat height of the chair was $39 \mathrm{~cm}$ and seat length $33 \mathrm{~cm}$. The height of the table was $71.5 \mathrm{~cm}$. The criteria used to classify the adequacy of the furniture were based on Parcells et al. [22]. Anthropometric measurements were obtained from popliteal height, thigh length, shoulder height and elbow height.From the quotient between seat height and popliteal height it was set the seat height match, and this value must be between 88 to $95 \%$ to an appropriate height seat.For the quotient between the seat length and thigh length, a value between 80 and $95 \%$ was considered appropriate. The adequacy of the tableheight was based at the elbow height and maximum recommended shoulder flexion and abduction angles, $25^{\circ}$ and $20^{\circ}$, respectively [7]

\subsection{Postural evaluation and audiovisual recordings}

Four inclinometers and a data logger were used for recording postures and movements for the head, upper back and upper arms. The sampling rate was $20 \mathrm{~Hz}$.

One inclinometer transducer was placed on the forehead and another to the right of the cervicothoracic spine at the C7-Th1 level. For the upper arms, the inclinometers were fixed to plastic plates that were placed along the upper arm just below the insertion of the deltoid muscle. For the head and upper back, the forward-backward and sideways projection of the inclination angle (flexion and inclination below) and their time derivatives were used to characterize postures and movements. Upper arm elevation and the time derivative of the position on the unit sphere (as described by spherical co-ordinates), were used for the postures and movements, respectively. Various percentiles of the angle and angular velocity distributions were calculated. The reference position for the head and upper back (flexion 0 degrees) was defined as the position obtained when the subject was standing upright and looking at a mark at eye level. The forward direction of the head and back was defined with the subject sitting, leaning straight forward, and looking at the floor. For the upper arms, the reference position (elevation 0 degrees) was recorded with the subject sitting, with the side of the body leaning towards the rest of the chair, with the arm 
hanging perpendicular over the rest of the chair, and with a $2-\mathrm{kg}$ dumbbell in the hand. The forward direction of the upper arms (elevation 90 degrees) was defined as the upper arms elevation at scapular plane. All data collection procedures were based on the protocol described by Hansson et al. [14].

After the calibration procedures, the student returned to the classroom and was instructed to perform their activities as naturally as possible. The researchers remained in the classroom and performed the audiovisual records with a digital camcoder. The mean recording duration was 78 min with standard deviation of $25 \mathrm{~min}$. In this Brazilian state school, students have six classes a day, with duration of 50 minutes each and a lunch break of 20 minutes after the first three classes (150 minutes). During the recording period of regular classes the main tasks performed by students are attending to the teacher/blackboard, reading/writing and a combination of these two tasks (mixed task). In general, Brazilian schools adopt a traditional teaching model, which is based on individual tasks and long periods in seated posture.

\subsection{Data analysis}

Data were descriptively analyzed, using mean and standard deviation. Postural and movement data were treated as percentiles. Correlational statistical analysis between furniture mismatch and posture data was applied. Variables that presented a $P$-value $\leq 0.25$ were included in a multiple linear regression model. This analysis was used to select explicative variables for furniture mismatch. Differences between groups and upper arms were tested by Mann Whitney and Wilcoxon tests, respectively. All analysis was performed using SPSS (version 11.5).

Two representative students, the lowest $\left(5^{\text {th }}\right.$ grade) and the highest ( $8^{\text {th }}$ grade), were selected for task analysis. The identified tasks were: 1 . attending to the teacher/blackboard; 2 . reading/writing and 3. a combination of these two tasks (mixed task).

\section{Results}

\subsection{Sample characteristics}

The final sample, after exclusion of two subjects due to technical problems, was composed by 46 students. The main subject's characteristics are presented in Table 1.

\subsection{Furniture evaluation}

The adequacy classification revealed that the seat height was inadequate in $57 \%$ of cases, the seat length in $56 \%$ and the table height in $81 \%$ of cases. Table 2 shows that for the $5^{\text {th }}$ grade, the seat height was high for many students although it was low for half of the $8^{\text {th }}$ grade students. Table height was high for most of the $5^{\text {th }}$ grade and low for many of the $8^{\text {th }}$ grade students. Considering the furniture as a conjunction, only one student had his seat and table adequate.

Spearman correlation coefficient $\left(r_{s}\right)$ was significant $(P<0.05)$ for stature and seat/popliteal height quotient $\left(r_{s}=-0.81\right)$; seat/thigh length quotient $\left(r_{s}=-\right.$ $0.78)$ and table/upper arm height $\left(r_{s}=-0.38\right)$; indicating that stature is an important predictor for furniture/student match.

\subsection{Postural evaluation and audiovisual recordings}

Postures and movements of head, upper back and upper arms are presented at Table 3. It can be seen that head movements showed small variations between groups, as well as upper back flexion. Head and upper back inclination were more pronounced for the left side.Upper back inclination wasinversely correlated with seat/thigh length quotient $\left(r_{s}\right.$ between -0.30 and -0.38 ), indicating that when the seat is short, the upper back left inclination increase.

Marked differences between groups were identified for upper back inclination and upper arms elevation. The $5^{\text {th }}$ grade students showed higher left upper back inclination and upper arms elevation. Right upper arm elevation showed positive correlation with seat/popliteal height quotient $\left(r_{s}=0.34\right.$ at $50^{\text {th }}$ and 0.41 at $90^{\text {th }}$ percentiles). Upper arms showed significant positive correlation with seat/thigh length quotient at $50^{\text {th }}$ and $90^{\text {th }}$ percentiles $\left(r_{s}\right.$ between 0.35 and $0.52)$. Right arm elevation at $90^{\text {th }}$ percentile showed positive correlation $\left(r_{s}=0.30\right)$ with table/arm height quotient. In general, velocities were low for all students and joints, with significant differences between groups at $90^{\text {th }}$ percentile for head and upper back flexion. The $8^{\text {th }}$ grade students showed higher velocities than $5^{\text {th }}$ gradeat $90^{\text {th }}$ percentile.Multiple linear regression analysis showed that seat/popliteal height quotient is explained by $90^{\text {th }}$ percentile of upper back inclination $(\beta=0.410)$ and $90^{\text {th }}$ percentile of right upper arm elevation $(\beta=-0.293)$. 
Table 1

\begin{tabular}{ccc}
\multicolumn{3}{c}{ Sample characteristics } \\
\hline \multirow{2}{*}{ CHARACTERISTIC } & GROUPS \\
\cline { 2 - 3 } & $(\mathrm{N}=24 ; 12$ boys, 12 girls $)$ & 8th grade \\
& mean $(\mathrm{SD})$ & mean $(\mathrm{SD})$ \\
age (years) & $11.5(1.1)$ & $14.9(0.9)$ \\
weight $(\mathrm{kg})$ & $41.7(10.7)$ & $59.3(12.5)$ \\
height $(\mathrm{m})$ & $1.5(0.1)$ & $1.7(0.1)$ \\
body mass index $\left(\mathrm{kg} / \mathrm{m}^{2}\right)$ & $19.1(3.8)$ & $21.7(4.7)$ \\
\hline
\end{tabular}

Table 2

Subject's and furniture main characteristics

\begin{tabular}{lcc}
\hline & \multicolumn{2}{c}{ GROUPS } \\
\cline { 2 - 3 } CHARACTERISTIC & $5^{\text {th }}$ & $8^{\text {th }}$ grade \\
& mean $(\mathrm{SD})$ & mean \\
& & $(\mathrm{SD})$ \\
popliteal height $(\mathrm{cm})$ & $40.3(3.5)$ & $44.9(2.1)$ \\
buttock-popliteal length $(\mathrm{cm})$ & $36.7(2.7)$ & $44.2(3.9)$ \\
elbow height $(\mathrm{cm})$ & $25.1(5.9)$ & $31.0(3.7)$ \\
shoulder height $(\mathrm{cm})$ & $47.6(3.8)$ & $54.3(2.5)$ \\
match seat height-popliteal height & $\mathrm{N}(\%)^{\mathrm{a}}$ & $\mathrm{N}(\%)$ \\
low & $5(23)$ & $11(50)$ \\
adequate & $8(36)$ & $11(50)$ \\
high & $9(41)$ & $0(0)$ \\
match seat length-buttock-popliteal length & $\mathrm{N}(\%)^{\mathrm{b}}$ & $\mathrm{N}(\%)$ \\
short & $1(5)$ & $19(86)$ \\
adequate & $16(76)$ & $3(14)$ \\
long & $4(19)$ & $0(0)$ \\
match table height-elbow-shoulder height & $\mathrm{N}(\%)^{\mathrm{a}}$ & $\mathrm{N}(\%)^{\mathrm{c}}$ \\
low & $4(18)$ & $8(38)$ \\
adequate & $2(9)$ & $6(29)$ \\
high & $16(73)$ & $7(33)$ \\
\hline${ }^{\mathrm{a}}$ Two of the original 24 students were excluded due to the lack of antropometric measurement. \\
${ }^{\mathrm{c}}$ Three of the original 24 students were excluded due to the lack of antropometric measurement. \\
\cline { 2 - 3 } One original 22 students were excluded due to the lack of antropometric measurement.
\end{tabular}

For seat/thigh length quotient the significant variables were $90^{\text {th }}$ percentile of upper back velocity $(\beta=-$ 0.282 ) and $90^{\text {th }}$ percentile of right upper arm elevation $(\beta=0.410)$.

\subsection{Task analysis}

Figures 1 and 2 shows the postural exposure of two representative subjects, the tallest one and the smallest one, performing different and common tasks at classroom. Total recording lasted 80 minutes for the $5^{\text {th }}$ grade student and 41 minutes for the $8^{\text {th }}$ grade student. Tasks duration were $11.3 \%$ and $9.8 \%$ of the total time for task 1 (watching classes, looking at the teacher or the blackboard), $48.8 \%$ and $17.1 \%$ for task 2 (writing or reading) and 28.8 and $39.0 \%$ for task 3 (mixed of tasks 1 and 2) for the $5^{\text {th }}$ and $8^{\text {th }}$ grade students, respectively. Students performed other activities during the recording time, as stand up and walk $(2.5 \%$ and $9.8 \%)$ and "unauthorized breaks" talking with friends ( $8.8 \%$ and $24.4 \%)$.

Task analysis showed an increased head and upper back flexion and left inclination for reading/writing task (task 2). Right upper arm elevation was higher for attending blackboard/teacher (task 1). Left upper arm showed small difference between tasks. In general, the lowest student showed greater exposure for all tasks.

\section{Discussion}

\subsection{Furniture evaluation}

Since the anthropometric dimensions differ between $5^{\text {th }}$ and $8^{\text {th }}$ grade students and the furniture dimensions are fix, most children have furniture that are inadequate, exposing them to ergonomic hazards. 
In this study the mismatch between furniture dimensions/anthropometric measurements was high for both grades.

Only one child have match with the whole furniture, i.e. seat height and length and table height were adequate. The other students have mismatch in the seat height $\left(64 \%\right.$ for $5^{\text {th }}$ grade and $50 \%$ for $8^{\text {th }}$ grade), seat length ( $24 \%$ for $5^{\text {th }}$ grade and $86 \%$ for $8^{\text {th }}$ grade) and table height $\left(81 \%\right.$ for $5^{\text {th }}$ grade and $71 \%$ for $8^{\text {th }}$ grade). These problems may lead to compensatory postures and behaviors, like sitting sideways and rocking on chairs [17]. It is hypothesized that the low seat can push the children towards the back of the seat when they were writing or working on the table. It is harder to sit forwards, and then the legs have to be tucked uncomfortably underneath the low seat. Thus, the lumbar andhip flexion is increased placing even more strain on lumbar discs [23]. On the other hand, long seat can leave the students away from the table, without using back support. This can increase neck and trunk flexion and upper arms elevation. The high table can also lead to higher upper arms elevation in order to reach the working surface.

Others studies found similar results. Panagiotopoulou et al. [21] found that none of the children measurements were in proportion to the chairs in length and the desk-chair combinations were inadequate for all the students in the $2^{\text {th }}$ and $4^{\text {th }}$ grades as well as the majority of those in the $6^{\text {th }}$ grade. Saarni et al. [24] evaluated 101 children in $6^{\text {th }}$ and $8^{\text {th }}$ grade to check the mismatch between furniture and anthropometric measurements and their findings were similar to the present study. These authors indicate that the school furniture did not match up with the schoolchildren's anthropometric measures

Table 3

Positions and movements of head, upper back and upper arms during regular classes. Mean and (SD) are shown for all $(n=46)$ students, and those from $5^{\text {th }}$ grade $(n=24)$, and those from $8^{\text {th }}$ grade $(n=22)$, at different percentiles of the angular and velocity amplitude distributions. For inclination angles, positive values denote bending to the right.

\begin{tabular}{|c|c|c|c|c|c|c|c|c|}
\hline \multicolumn{2}{|c|}{ Distribution (percentile) } & \multirow{2}{*}{$\begin{array}{l}\text { Group of } \\
\text { students }\end{array}$} & \multicolumn{2}{|c|}{ Head } & \multicolumn{2}{|c|}{ Upper back } & \multicolumn{2}{|c|}{ Upper arms elevation } \\
\hline & & & Flexion & Inclination & Flexion & Inclination & Right arm & Left arm \\
\hline \multirow[t]{9}{*}{ Positions $\left({ }^{\circ}\right)$} & 10th & All & $-7(7)$ & $-15(8)$ & $-2(7)$ & $-14(6) \dagger^{x}$ & $27(14)^{x}$ & $27(15)^{x}$ \\
\hline & & 5 th grade & $-7(7)$ & $-17(7)$ & $0(7)$ & $-17(5)$ & $32(15)$ & $32(15)$ \\
\hline & & 8 th grade & $-6(7)$ & $-13(9)$ & $-4(8)$ & $-11(5)$ & $22(12)$ & $22(13)$ \\
\hline & 50 th & All & $9(9)$ & $-2(6)$ & $12(9)$ & $-4(10) \dagger^{x}$ & $52(12)^{*} \dagger^{x}$ & $54(14) \dagger^{x}$ \\
\hline & & 5 th grade & $8(7)$ & $-3(4)$ & $14(7)$ & $-7(5)$ & $56(9)$ & $59(13)$ \\
\hline & & 8 th grade & $10(10)$ & $-1(8)$ & $10(10)$ & $0(13)$ & $47(13)$ & $50(15)$ \\
\hline & 90th & All & $33(11)$ & $10(9)$ & $28(8)$ & $5(10) \dagger^{x}$ & $68(10)^{*}+\#^{x}$ & $68(12) \dagger^{x}$ \\
\hline & & 5 th grade & $31(11)$ & $8(6)$ & $28(8)$ & $1(7)$ & $71(9)$ & $73(9)$ \\
\hline & & 8 th grade & $35(10)$ & $12(12)$ & $27(8)$ & $10(12)$ & $64(11)$ & $63(13)$ \\
\hline \multirow[t]{9}{*}{ Velocities $(\% / s)$} & 10 th & All & $1(0)$ & $1(0)$ & $1(0)$ & $1(0)$ & $2(1)$ & $2(1)$ \\
\hline & & 5 th grade & $1(0)$ & $1(0)$ & $1(0)$ & $1(0)$ & $2(1)$ & $2(1)$ \\
\hline & & 8 th grade & $1(0)$ & $1(0)$ & $1(0)$ & $1(0)$ & $2(1)$ & $2(1)$ \\
\hline & 50th & All & $6(2)$ & $9(3)$ & $4(2)$ & $4(2)$ & $10(4)$ & $9(4)$ \\
\hline & & 5 th grade & $6(2)$ & $9(2)$ & $4(2)$ & $4(1)$ & $10(4)$ & $9(3)$ \\
\hline & & 8th grade & $7(2)$ & $9(3)$ & $4(2)$ & $4(3)$ & $10(4)$ & $9(4)$ \\
\hline & 90th & All & $38(11) \dagger^{x}$ & $50(14)$ & $26\left(9^{x}\right.$ & $24(11)$ & $58(16)$ & $55(16)$ \\
\hline & & 5 th grade & $33(9)$ & $46(12)$ & $24(7)$ & $22(6)$ & $56(16)$ & $52(14)$ \\
\hline & & 8th grade & $43(11)$ & $53(14)$ & $29(10)$ & $27(14)$ & $61(16)$ & $59(18)$ \\
\hline \multirow{2}{*}{\multicolumn{9}{|c|}{$\begin{array}{l}\text { * Statistically significant correlation (Spearman rank order correlation) between seat/popliteal height quotient and posture }(\mathrm{P}<0.05) \\
\text { † Statistically significant correlation (Spearman rank order correlation) between seat/thigh length quotient and posture }(\mathrm{P}<0.05)\end{array}$}} \\
\hline & & & & & & & & \\
\hline \multicolumn{9}{|c|}{$\begin{array}{l}\text { † Statistically significant correlation (Spearman rank order correlation) between seat/thigh length quotient and posture }(\mathrm{P}<0.05) \\
\text { \# Statistically significant correlation (Spearman rank order correlation) between table/arm height quotient and posture }(\mathrm{P}<0.05)\end{array}$} \\
\hline
\end{tabular}



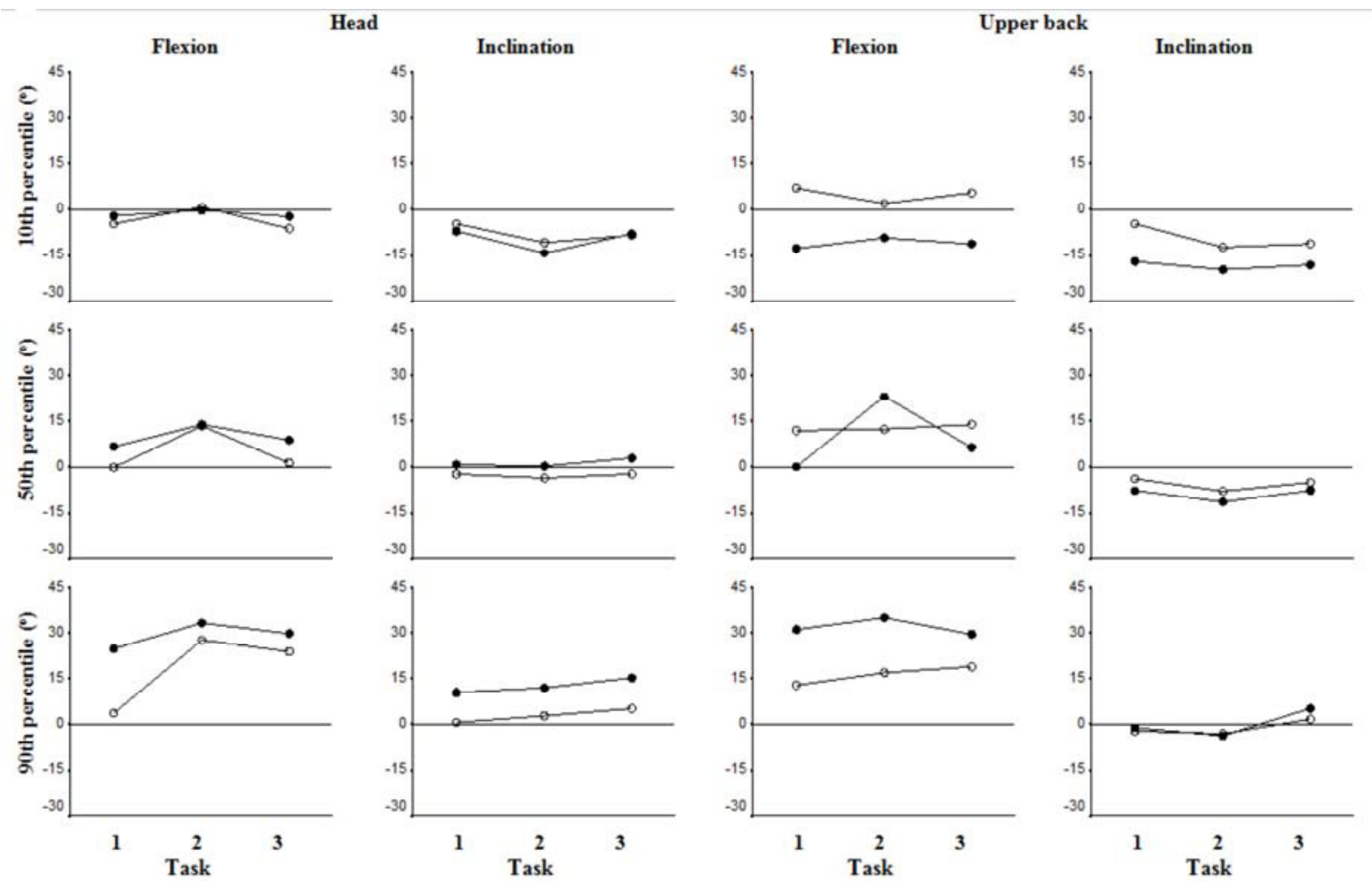

Fig. 1. Head and upper back posture and movements for three separate tasks. Full circle represents the lowest student ( $5^{\text {th }}$ grade) and empty circle represents the highest student $\left(8^{\text {th }}\right.$ grade). Task 1: watching classes, looking at the teacher or the blackboard; Task 2:writing or reading using the table how a support; Task 3: a mixed of previous tasks.
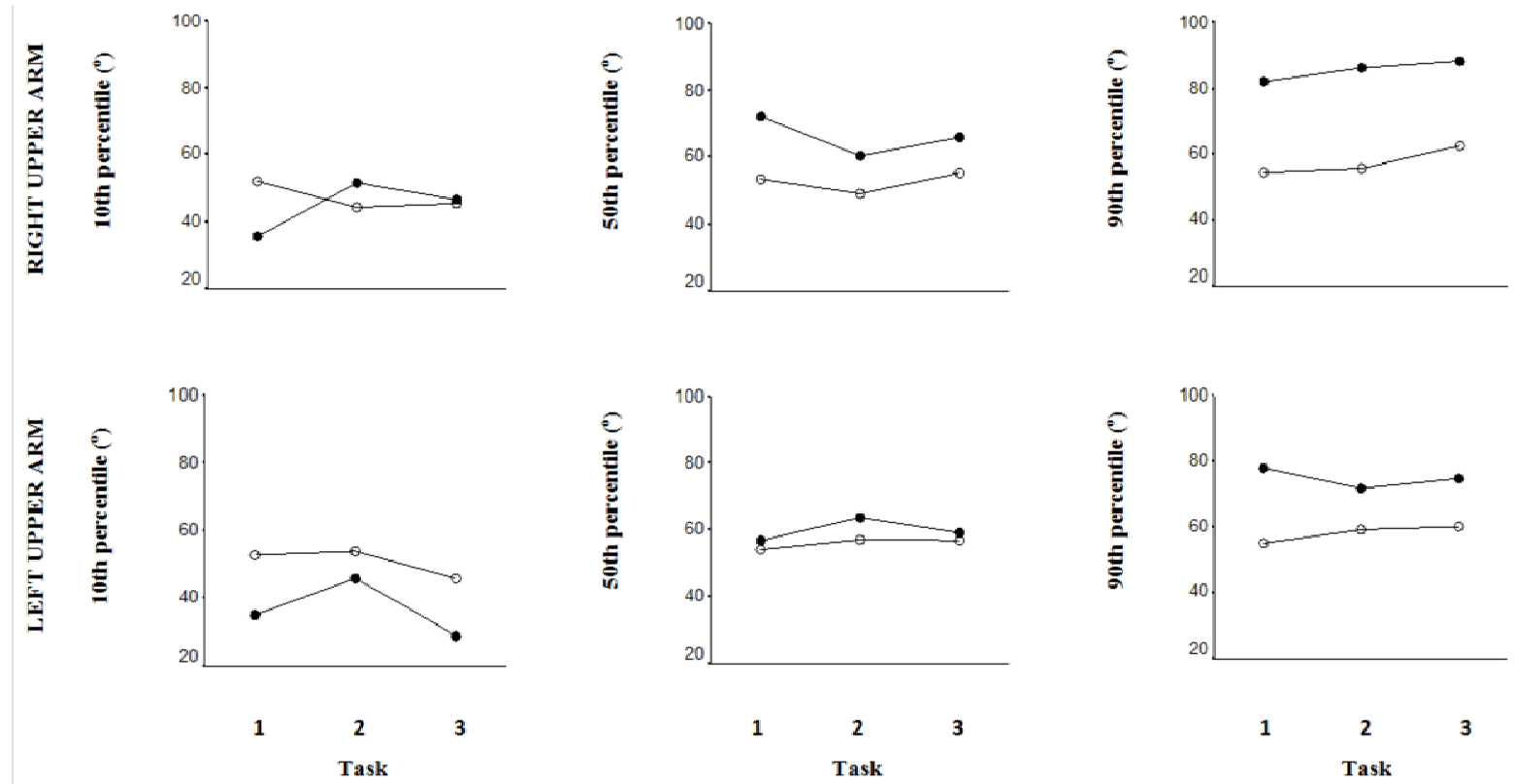

Fig. 2. Right and left upper arm elevation for three separate tasks. Full circle represents the lowest student $\left(5^{\text {th }}\right.$ grade) and empty circle represents the highest student $\left(8^{\text {th }}\right.$ grade). Task 1: watching classes, looking at the teacher or the blackboard; Task 2:writing or reading using the table how a support; Task 3: a mixed of previous tasks. 
A wide prevalence range of thoracic spine pain was found in the literature, prevalence estimates in children described in a systematic review were up to $38 \%$ among males and up to $72 \%$ among females [6]. This review also describes that one of the risk factors for this is furniture mismatch.

Stature or body height is shown to be a good predictor of whether a student fits into a chair [22]. The significant correlation found in this study corroborate with the literature in this topic.

Others studies have evaluated the student's posture at classroom. Geldhof et al [11] studied the posture of 41 students of the $4^{\text {th }}$ and $5^{\text {th }}$ grade with PEO method (Portable Ergonomic Observation). The findings indicate the postural pattern of elementary schoolchildren was commonly prolonged sitting with a poor posture. Children sat statically for $85 \%$ of the time, while their trunk was bent over $45^{\circ}$ for $28 \%$ of the lesson time. A possible biomechanical consequence of these findings may be increased intradiscal pressure resulting in decreased nutrition to the disc, a risk factor for early degenerative changes and back or neck pain. The association between observed postures and back/neck pain was weak, most likely because the effects of spinal loading do not occur until an older age.

\subsection{Postural evaluation}

For each joint, standard postures can be defined on that maintenance requirements are minimal and anatomical structures are in favorable positions. Any deviation from these postures can lead to consequences for the musculoskeletal system if maintained for long time without muscular rest [13]. Posture affects comfort and performance at work [4] and may be an important cause of pain and discomfort [9]. As a result, the postural assessment is crucial when the goal is to increase comfort and reduce musculoskeletal symptoms. Different studies suggest favorable range of motion for head, upper back and upper arms postures for adults during occupational tasks; few of them report this data for children and adolescents.

Our findings indicate that students remain at highest degrees of head flexion $\geq 33^{\circ}$ and upper back flexion $\geq 28^{\circ}$ for $10 \%$ of the time; and $\geq 7^{\circ}$ of head extension and $\geq 2 \circ$ of upper back extension for $10 \%$ of the time. They also had a lateral inclination in much of the time, especially for left side. This can be explained by manual dominance, as all students are right-handed, so they are looking at what they are doing with their right hand and bend their head/upper back towards the left to be able to do this.

Ariëns[3] states that head/upper back postures should be kept in between $0^{\circ}$ and $25^{\circ}$ of flexion and Hagberg et al. [13] suggest that head/upper back lateral inclination must be avoided during long periods of time. Akesson et al. [1] described that the combination of flexion and lateral inclination is more strained than the pure flexion and implies higher load on the cervical/upper back spine. According Smyth and Haslam [26] any range of head extension is considered unsafe. Sakakibara et al. [25] describe that work with fully extending of the head may lead to symptoms of vertebral artery insufficiency. Thus, schoolchildren are exposed to awkward head postures during classes and this exposure is higher during writing/reading task when the student is looking downwards.Results from occupational literature suggest that shoulder elevation greater than $30^{\circ}$ is considered a risk factor of developing acute pain in the neck/shoulder and musculoskeletal disorders [5]. Another common exposure factor is long periods of time with the arm in an abducted or flexed position without support [15]. Jacobs and Baker [16] investigated the association between children's computer use and musculoskeletal discomfort and found that almost half of $6^{\text {th }}$ grade students had experienced some musculoskeletal discomfort in at least one body part, with the most common areas of moderate to severe discomfort being the neck, back and shoulders.

Our findings showed high angles for upper arm elevation and significant correlation with seat length and table height match. Especially for $5^{\text {th }}$ grade where the seat was long for $19 \%$ and the table was high for $73 \%$. Both situations lead to high overload in the upper arms, reaching up to $68^{\circ}$ of elevation for both arms.Results showed no difference between right and left upper arm elevation, indicating a symmetrical load at these joints.

\subsection{Task analysis and velocities}

From the task analysis it can be seen that the students perform the tasks that offer higher postural risk (tasks 1 and 2 ) by $60 \%\left(5^{\text {th }}\right.$ grade) and $26.8 \%\left(8^{\text {th }}\right.$ grade) of the time. In accord with Knight and Noyes [17], a chair and table should be designed to provide support for the two major tasks of the students: attending to the teacher and writing on the working surface. These tasks require adoption of quite different physical positions by the child, and the furniture need to provide the better conditions for this. 
In general, velocities were low for all students and joints. The $8^{\text {th }}$ grade students showed higher velocities than $5^{\text {th }}$ grade at $90^{\text {th }}$ percentile, indicating that older students are more "active". One possible explanation for these is that they had 'off-task' periods (stand up and unauthorized breaks) longer than the $5^{\text {th }}$ grade students. Knight and Noyes [17]also described that another function of the furniture should be to facilitate learning through providing a comfortable and stress-free workstation. In order to achieve this, it is generally accepted that classroom furniture needs to be designed to allow the children to move about in their seats, as it is unnatural to keep still for long periods [18].

This study showed a relationship between furniture mismatch and postural overload. The evaluated school offers only one type of furniture with fixed dimensions for all students. The ones from extreme gradesare the ones that are more exposed to ergonomic risks at school. Thus, we can suggest for educational managers to consider the ergonomic risks that our children are exposed in school, providing different types and sizes of furniture.

\section{Acknowledgements}

National Council for Scientific and Technological Development (CNPq) Proc. N. 476524/2008-3

\section{References}

[1] Akesson I, Hansson GA, Balogh I, Moritz U, Skerfving S. Quantifying work load in neck, shoulders and wrists in female dentists. Int Arch Occup Environ Health v.69 p.461-474, 1997.

[2] Ariens GA, Bongers PM, Douwe SMC, Miedema WE, Hoogendoorn G, Bouter LM, Mechelen VW. Are neck flexion, neck rotation, and sitting at work risk factors for neck pain? Results of a prospective cohort study. Occup Environ Med 58:200207, 2001.

[3] Ariens GA, Bongers PM, Hoogendoorn WE, van der Wal G, van Mechelen W. High physical and psychosocial load at work and sickness absence due to neck pain. Scand J Work Environ Health v. 28 p. 222-31, 2002.

[4] Bhatnagar V, Drury CG Schiro SG. Posture, postural discomfort and performance. Hum Factors v.27 n.2 p.189-99, 1985.

[5] Bjelle A, Hagberg M, Michaelson G. Ocuppational and individual factors in acute shoulder-neck disorders amog industrial workers. Br J Ind Med v. 38 p. 356-63, 1981.

[6] Briggs AM, Smith AJ, Straker LM, Bragge P. Thoracic spine pain in the general population: Prevalence, incidence and associated factors in children, adolescents and adults. A systematic review. BMC Musculoskeletal Disorders v. 10 n. 77 p.1-12, 2009.

[7] Chaffin D, Anderson G. Occupational biomechanics. New York: Wiley, 1991.

[8] Chung JWY, Wong TKS. Anthropometric evaluation for primary school furniture design. Ergonomics v.50 n.3 p.323-334, 2007.

[9] Coury, 1999 Coury HJCG. Postural recording. Capítulo de encyclopedia: Industrial Ergonomics: User's Encyclopdeia, 1999.
[10] Cranz G. The Alexander Technique in the world of design: posture and the common chair. J Bodywork Movement Ther, 4(2), 90-98, 2000

[11] Geldhof E, Clercq D, Bourdeaudhuij I, Cardon G. Classroom posture of 8-12 year old children. Ergonomics v. 50 n.10 p.1571-1581, 2007

[12] Gil HJC, Tunes E. Posture recording: a model for sittting posture. Applied Ergon v.20 n.1 p.53-7, 1989.

[13] Hagberg et al., 1995 Hagberg M. ABC of work related disorders: neck and arm disorders. British Medical Journal, v. 313, p. 419-422, 1996.

[14] Hansson G- $\AA$, Balogh I, UngeByström J, Ohlsson K, Nordander C, Asterland P, Sjölander S, Rylander L, Winkel J, Skerfving S, Malmö Shoulder-Neck Study Group. Questionnaire versus direct technical measurements in assessing postures and movements of the head, upper back, arms and hands. Scand J Work Environ Health v. 27 n.1 p.30-40, 2001.

[15] Hansson GA, Balogh I, Ohlsson K, Granqvist L, Nordander C, Arvidsson I, Åkesson I, Unge J, Rittner R, Strömberg U, Skerfving S. Physical workload in various types of work: Part II. Neck, shoulder and upper arm. International Journal of Industrial Ergonomics v. 40 n. 3 p. 267-281, 2010

[16] Jacobs K and N.A. Baker, The association between children's computer use and musculoskeletal discomfort, Work 18 (2002), 221-226.

[17] Knight G, Noyes J. Children's behaviour and the design of school furniture. Ergonomics v.42 n.5 p.747-760, 1999

[18] Laville A. Postural stress in high-speed precision work. Ergonomics v.28 n.1 p. 229-236, 1985.

[19] Limon S, Valinsky LJ, Ben-Shalom Y. Children at riskrisk factors for low back pain in the elementary school environment. Spine 29(6), 697-702, 2004.

[20] Linton SJ, Hellsing A-L, Halme T, Åkersted K. The effects of ergonomically designed school furniture on pupils' attitudes, symptoms and behavior. ApplErgon, 25(5):299-304, 1994.

[21] Panagiotopoulou G, Cristoulas K, Panpancklaou A, Mandroukas K. Classroom furniture dimensions and antropometric measures in primary school. Applied Ergonomics, 35:121-128 2004.

[22] Parcells C, Stommel M, Hubbard RP. Mismatch of classroom furniture and student body dimensions. Journal of adolescen health v. 24 p. $265-273,1999$

[23] Petersen S, Brulin C, Bergstrom E. Recurrent pain symptoms in young schoolchildren are often multiple. Pain,121:14550,2006 .

[24] Saarni L, Nygård CH, Rimpelä A, Nummi T, Kaukiainen A. The working postures among schoolchildren - A controlled intervention study on the effects of newly designed workstations. Journal of School Health v.77 n.5 p.240-247, 2007

[25] Sakakibara H, Miyao M, Kondo T, Yamada S, Nakagawa $\mathrm{T}$, Kobayashi F. Relation between overhead work and complaints of pear and apple orchard workers. Ergonomics v. 30 p. 805-15, 1987.

[26] Smyth G, Haslam R. Identifying risk factors for the development of work-related upper limb disorders. In Robertson, SA (Ed.) Contemporary Ergonomics. Taylor \& Francis, p.440-45, 1995.

[27] Trevelyan FC, Legg SJ. Back pain in school children where to from here. Applied Ergonomics v.37 n.1 p.45-54, 2006

[28] Wingrat JK, Exner CE. The impact of school furniture on fourth grade children's on-task and sitting behavior in the classroom: A pilot study. Work v.25 p.263-272, 2005. 